\title{
SYMPOSIUM
}

\section{Monday 7 a.m.}

\section{One of Five Pieces}

\section{Malcolm Parker}

Received: 5 November 2013 / Accepted: 5 December 2013 /Published online: 17 May 2014

(C) Springer Science+Business Media Dordrecht 2014

I found a man

in a room

sprawl awkward

at a dying angle

ticking

at his bed's end

at his life's end

past the end of his wits

and his wife's

in a room

round the end of their lives.

He trembled his vows again

held his cachectic belle

past her life's end

their last toast the mercy kill.
I found him

ticking slowly

she cold

delivered

waiting on his life.

His survival

obliging inquiry

of motive

of method

I hurried

him off to her

gentlest of homicides.

Two mounds in a room, cooling past fear, post suicide.

M. Parker $(\bowtie)$

School of Medicine, University of Queensland,

Brisbane, Australia

e-mail: mfmparke@somc.uq.edu.au 